\title{
Riverside restoration - city planner's viewpoint: case of Mutha riverfront, Pune, India
}

\author{
S. Barve \& S. Sen \\ Department of Architecture and Regional Planning, IIT Kharagpur, India
}

\begin{abstract}
Rivers play a major role in shaping the development of cities, as many major ones across the world have originated by the banks of rivers. Such river systems have not only been used for irrigation, drainage and supply of potable water but they also possess a close relationship with the social fabric. The Mutha riverfront in Pune is multi functional with bulk of its premises being residential, commercial and institutional buildings along with some heritage structures. The rapid urbanization of the city has adversely affected the river with various forms of pollution, becoming a major issue for the city authority. This phenomenon has lead to the detachment of the city from the river. In view of this demographical change, it becomes essential for any city authority to restore such a valuable resource to its lost glory, thereby enhancing its appropriate role in transforming the vacant riverfront to a place of planned development. The study provides a set of planning and design principles that will allow communities to reclaim urban river edges in the most ecologically sound and economically viable manner. This study would also guide planners, mayors, public works departments, environmental officials, river advocates, and the general public in their search for effective riverfront restoration covering key topics related to human interaction with rivers and providing a set of essential strategies to help communities to achieve more with their riverfront revitalization efforts.
\end{abstract}

Keywords: urban rivers, water front, water quality, mixed-use, land suitability index, riverfront zone, CDP Pune. 


\section{Introduction}

By definition an urban river is a stretch or section of a water resource located within a catchment that contains a town or a city, where the structure and function of that water resource is altered from its natural state, (Henning et al [1]). These river systems are not only used for irrigation, drainage and supply of potable water but they also have a close relationship with the social fabric (Petts [2]). However due to the pressure of urbanization and population growth, riverfront areas are getting degraded in terms of poor water quality, limited access, formation of slums etc. and are often found functioning as open sewers or dumping grounds. Such problems are not only confined to a particular geographic region of the world, but also common to all places subject to urbanization where India is no exception.

One can see many examples [3-5] across the world, where city authorities have made successful efforts to reconnect people to the river by reshaping their riverfronts like in Portland, Boston, Seattle, San Francisco, and Tokyo. Major development projects in India like the Ganga action plan, Yamuna action plan, Sabarmati riverfront development has been initiated to improve the river environment.

Waterfronts have a long history of changing types and levels of uses and are now coming back into potentially thriving and layered public use. Waterfronts can be developed with different functions and activities like parklands, recreational public place and as a retail or tourist centre (Ryckbost [6]). However studies suggest that mixed use development along the waterfront is ideally suitable and beneficial; both for the community and city authorities as it not only provides wide public access to the riverfront but also contribute in the economic development of the city.

The study here focuses on the development of the Mutha riverfront in Pune. The main objective here is to suggest suitable planning strategies for adoption thereby transform the riverfront to a place where people can live, work and utilise and give them back the same riverfront through improvements in public access and addition of green spaces along river edges making the riverfront serve more than one purpose.

\section{Highlights of the study area}

Pune is one of the fastest growing cities with a population of 2.5 million residents (2001 census of India) and a decadal growth rate of more than $40 \%$. This high growth is mainly due to migration from all over the country. It is also very well connected to other metro cities by rail, road and air. Mutha River, Mula River and Mula- Mutha River are the three major water bodies in the city which divides it into three major sectors. Mutha River originating from the western ghats of India is the principal source of water supply to the city. The flow in the river (south west to north east) has been controlled by the construction of Khadakwasla dam. The total length of the river within the city is 
$10 \mathrm{~km}$ with an average width of 150 to 225 metres and an average depth of around 2 to 3 metre (CDP Pune [7]).

The Mutha riverfront is multi functional with majority of the premises being residential, commercial and institutional buildings along with some heritage structures. Rapid urbanization of the city has adversely affected the river with various forms of pollution, which has become a major issue for all concerned city authorities (JNNURM Department [8]). This phenomenon has lead to detachment of the city from the river. In order to initiate such an exercise in an integrated manner, the study area has been delineated considering the following important criterions i.e.

- Two major transportation corridors running parallel on both sides of the river as the limit.

- Commutable distance from the riverfront varying from $200 \mathrm{~m}$. to $1200 \mathrm{~m}$.

- $\quad$ Population Density ranging from 8000 to 90,000 persons per sq. km.

- Catchment area of Major nallahs/creeks meeting the river.

Thus the total river stretch of $10 \mathrm{~km}$ is broadly divided into 4 stretches depending on the land use characteristics and functions of that area, fig. 1. The stretch 3 and stretch 4 are located within the central area of the city whereas stretch 1 and stretch 2 are located in the fringe and middle zone of the city respectively. For the planning purpose these four stretches are again divided into 13 sub-zones marked as A-M.

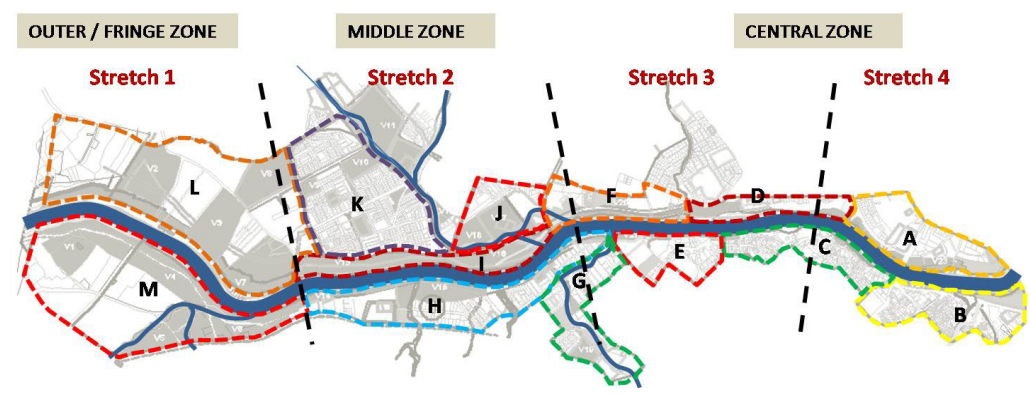

Figure 1: $\quad$ Delineated study area.

\section{Characteristics of the river stretch}

Stretch-1 is characterized mainly by residential development with combination of plotted and multi-storeyed housing. Out of its net area, around 30\% land is lying vacant. The density of this stretch is between 8000 to 12000 persons $/ \mathrm{sq} \mathrm{km}$. There lies limited connectivity between the two banks of the river. River water quality is comparatively good while its side areas have the potential for residential development.

Stretch-2 is characterized by residential development. The density of this stretch lies between 15000 to 20000 persons/sq.km, greater than stretch -1 . Slums and encroachments are observed around the river bed near the 
nallas/creeks joining the river. This stretch has the maximum number of drains and nallas carrying waste water and untreated sewage into the river. Due to availability of vacant land this stretch has the maximum potential for providing amusement, recreation, entertainment and commercial activities along the river.

Stretch-3 is characterized by a kind of mixed use development having major commercial areas, educational campuses, some recreational places and a few heritage structures along the river. The density of this stretch varies between 20,000 - 30,000 persons/sq.km. It has the maximum number of connection between the two banks and better accessibility compared to other stretches due to location of crematoriums, temples and some parks.

Interestingly stretch-4 consists of govt, semi govt buildings with major administrative functions on the left side bank of the river. Squatter and slum settlements are observed on some areas near the railway station. There is no direct accessibility to the river from the major roads due to the topographic condition of that area. The right side of this river is within the congested area of the city with the density of around 80,000 to 90,000 persons/sq.km, highest within all the stretches. No vacant land is available on the river side.

\section{Overview of literature}

Previous studies (Marshall [9], Wakefield [10] and [11, 12]) indicate that every project had different focus for riverfront development varying from landscaping and recreation to commercial exploitation of prime land to conservation of heritage and religious function. Furthermore, experts recommended five key principles for due consideration while drawing proposals for Sustainable Development of Urban Waterfront Area during the Global Conference of the Urban Future (URBAN 21 conference, Berlin, 2000). These key principles act as a basis in suggesting a set of future guidelines for riverfront development (Moretti [13]). These principles are:-

- Secure the quality of water and the environment

- Waterfront to be conceived as an integral part of the existing urban fabric

- Collective heritage of water and city to be utilized

- Mixed use to be given priority

- Public access is a pre-requisite

\section{Survey procedure}

Three different types of surveys were carried out with the help of student enumerators during the month of October-November, 2008 in Pune. Firstly Public opinion survey was conducted within 150 randomly selected households to find out the varied opinion of public regarding issues like; impression of the people about the river and riverfront areas, preferred activities and places for recreation, reasons for the people not visiting the riverfront, type of development tailor made along the riverfront, strengths and weaknesses of the riverfronts, and the problems associated with the people residing on the riverfront. Secondly the survey also took the opinion of the local authority on the following issues; type 
of development most appropriate along the riverfront, current work and priorities, fund allocation and ownership of the riverfront land.

Thirdly the survey undertook a visual reconnaissance along the delineated study area to find out the activities along the river channel, garbage disposal points and skyline of the riverfront. All the different surveys revealed interesting facts and figures discussed and analyzed herein after.

\section{Survey findings}

\subsection{The result of the public opinion survey revealed the following}

\subsubsection{Preferred place for recreation}

Out of the total samples surveyed, more than $90 \%$ respondents preferred to visit movies, malls, restaurants and parks, whereas sports activities are enjoyed only by $65 \%$ of the people.

\subsubsection{Frequency of visit}

Interestingly outdoor recreational places such as parks, gardens and sports activities are visited daily by the people of Pune. The other recreation places like movies, malls and restaurants are visited weekly or even monthly by more than $75 \%$ of the people. Monuments and museums are usually visited once in a year.

\subsubsection{Travelling distance up to recreational place}

People preferred to travel up to 1 to $2 \mathrm{~km}$ for daily recreational visits and 4 to 5 $\mathrm{km}$ to places which are visited weekly and/or monthly. For the other important places of recreation which are not so frequently visited, people were ready to travel even up to $10 \mathrm{~km}$.

\subsubsection{Preferred time of visit to recreational place}

Preferred time to visit these places was after 6 p.m. in the evening. However the places like museums and monuments were often visited during the period of 3 to $6 \mathrm{pm}$ in the afternoon.

\subsubsection{Problems due to nearness to river}

One of the major problems faced by the people as well as the civic authorities was the dumping of solid waste along the riverfront. Out of the total samples surveyed $45 \%$ were of this opinion. Few areas also had the nuisance from slums and the problem of flooding.

\subsubsection{Willingness to pay}

Of the total samples surveyed, more than $60 \%$ of the respondents were of the opinion to pay more than Rs.25 per person per day for such outdoor riverfront recreation.

\subsubsection{Type of development on riverfront}

Out of the net samples surveyed, more than $50 \%$ of the respondents preferred recreational activities along the river. 


\subsection{Secondary survey conducted from various authorities reveal}

\subsubsection{Land use distribution}

Existing Land use distribution for the city as well as for the study area reveal that the Mutha riverfront belt of Pune to be multi functional. Of the total area in the riverfront about $54 \%$ of land is pre dominantly occupied by residential use only. Most of the government buildings, educational and institutional buildings, heritage structures and major commercial areas are located in the riverfront belt.

\subsubsection{Density pattern of the riverfront area}

The riverfront belt shows large amount of variation in the density pattern. The population density varies from $80,000 \mathrm{per} / \mathrm{sq} \mathrm{km}$ within the core area of the city to $5000 \mathrm{per} / \mathrm{sq} \mathrm{km}$ in fringe areas going from the core city area to sub-urban areas.

\subsubsection{Activity pattern of the riverfront area}

Though the riverfront offers large chunk of vacant lands, the activities observed along the river are limited. The major activities observed along the river are cremation activities, some religious activities, dhobi ghats (clothes washing) and idol immersion during festivals.

\subsubsection{Existing transportation system}

The study area is delineated within two major transportation corridors i.e. Karve road and Sinhgad road. These roads running parallel to the river connect central business district to the fringe residential areas. The study areas contain major transportation nodes through which maximum traffic movements take place. A total of 11 bridges connect the two banks of the river.

\subsubsection{Parking scenario}

There are a total of 14 parking lots which are developed by Pune Municipal Corporation with a capacity of 7000 two wheelers and 2000 four wheelers. Out of them, only four parking lots are located within the study area which is not sufficient for the existing traffic load. Lack of sufficient parking lots and organized on-street parking facilities have resulted in wayward and unorganized parking in most of the stretches. The capacities of the roads are also reduced by vehicles parked on the roadsides.

\subsubsection{Existing sewage disposal}

The treatment plants are not adequate for handling 576 million litres of sewage generated every day. Thereby a little less than $50 \%$ of the sewage generated (271 MLD) is directly disposed into the river without treatment causing severe water pollution. The ground water gets polluted as a result of huge volumes of sewage percolating through soil and infiltrating into the water table. Moreover due to limited capacity of the pumping station, drainage water is pumped out during restricted intervals, leading to a high drainage flow during the peak hours (CWPRS [14]). 


\subsubsection{Observations on river water quality}

There are total five monitoring stations which are located along the river and nallas set up by the Pune Municipal Corporation. The dissolved Oxygen level (DO) at source is $7-8 \mathrm{mg} / \mathrm{l}$, which is quite good for aquatic life and is also capable of oxidising organic matter. It was also found that the $\mathrm{pH}$ value of the river water is well within permissible limits of 6.5 to 8.5 for most part of the year. Hence it may be inferred that the river water is suitable for use of domestic uses. Interestingly river water was found to be most polluted in stretch 2 and in stretch 4 only due to nallas/creeks discharging polluted water into the river and due to the existence of slums near the confluence of the two rivers (Environmental Lab [15]).

\section{Approach from a planning perspective}

After the study of the existing situation of riverfront area in Pune three major issues were identified that needed further investigation in details, based on which the proposals were drawn up later.

\subsection{Issues related to land use}

Identifying spatial distribution of existing land use and identify activities harmful to the river, shifting incompatible functions from the riverfront area, identifying the potential of lands lying alongside the river for better use, checking and controlling the development within the immediate vicinity of the river.

\subsection{Issues related to transport}

Recommending the possible changes in the existing transportation system to serve the proposed riverfront developmental projects and activities along the river.

\subsection{Environmental issues}

Controlling the flow into channels, finding ways to regulate disposal of untreated sewage and effluent in the river, sewage treatment and pollution control, regulating the uses that are harmful to ecological balance, relocation of slums, and regulations for dumping of waste and flood protection.

\subsection{Concept of land suitability matrix for land use allocation}

There are different approaches and models which can be used for the allocation of different functions to vacant lands along the river. One of such an approach is to establish an appropriate land use criteria for the construction of land suitability matrix. Land suitability analysis is the process of determining the fitness of a given tract of land for defined use (Steiner et al. [16]). This method is used to assess the capability of land for future land uses, as well as the constraints and 
opportunities for future land development. In this matrix a value ranging from 1-4 is assigned for each sub-zone depending upon its suitability against each factor under a specific land use category. Thus each vacant land is earmarked under four categories e.g. highly suitable, suitable, moderately suitable and least suitable for each land use function.

Land suitability matrix was constructed for each of the five major land uses that were identified on the basis of earlier literature review and its practical utility for river side use of land. They were recreational, public-semi public, residential, commercial and religious land use respectively.

Table 1 shows the land suitability matrix for recreational land use as an example here. All the factors required for recreational function are noted along the columns and all the individual vacant lands are along the rows. Each vacant land is analysed against each function and appropriate score (1-4) was assigned on the basis of the requirement of that specific function. The scores for each factor were then added horizontally to find out the net score. Vacant lands having maximum scores were identified as most suitable for that particular land use (as shown in yellow patches here for recreational purpose). The same procedure was repeated for all other appropriate land uses and thus the proposed land use map was prepared. All the criteria noted in the columns for land suitability matrix were assumed to have equal weight age for this study.

Table 1: $\quad$ Land suitability matrix for recreational land use.

\begin{tabular}{|c|c|c|c|c|c|c|c|c|}
\hline vacant lands & $\begin{array}{c}\text { accessibility } \\
\text { by public } \\
\text { transport }\end{array}$ & $\begin{array}{l}\text { accessibility } \\
\text { by private } \\
\text { transport }\end{array}$ & $\begin{array}{l}\text { parking } \\
\text { facilities }\end{array}$ & $\begin{array}{c}\text { topographical } \\
\text { features of the } \\
\text { land }\end{array}$ & $\begin{array}{c}\text { eco sensitive } \\
\text { areas }\end{array}$ & $\begin{array}{c}\text { visual } \\
\text { connectivity with } \\
\text { the river }\end{array}$ & $\begin{array}{l}\text { compatibility } \\
\text { with the } \\
\text { surrounding } \\
\text { landuses }\end{array}$ & total \\
\hline V1 & 1 & 3 & 2 & 2 & 4 & 3 & 1 & 16 \\
\hline V2 & 2 & 3 & 2 & 2 & 4 & 3 & 2 & 18 \\
\hline V3 & 2 & 2 & 2 & 3 & 4 & 3 & 1 & 17 \\
\hline V4 & 1 & 3 & 2 & 1 & 4 & 4 & 2 & 17 \\
\hline V5 + V6 & 4 & 4 & 2 & 4 & 4 & 4 & 1 & 23 \\
\hline V7 & 2 & 3 & 2 & 2 & 4 & 3 & 2 & 18 \\
\hline V8 & 3 & 3 & 2 & 3 & 4 & 2 & 4 & 21 \\
\hline $\mathrm{V} 9+\mathrm{V} 10$ & 3 & 3 & 2 & 4 & 4 & 1 & 3 & 20 \\
\hline V11 & 4 & 4 & 2 & 2 & 4 & 2 & 2 & 20 \\
\hline V12 & 3 & 3 & 2 & 3 & 4 & 2 & 3 & 20 \\
\hline V13 & 2 & 4 & 2 & 4 & 4 & 4 & 3 & 23 \\
\hline V14 & 4 & 3 & 2 & 3 & 2 & 4 & 3 & 21 \\
\hline V15 & 4 & 3 & 2 & 3 & 4 & 4 & 3 & 23 \\
\hline $\mathrm{V} 16+\mathrm{V} 17$ & 3 & 4 & 2 & 4 & 4 & 3 & 4 & 24 \\
\hline V18 & 3 & 4 & 2 & 4 & 4 & 4 & 4 & 25 \\
\hline V19 & 4 & 2 & 2 & 2 & 4 & 2 & 2 & 18 \\
\hline V20 & 2 & 4 & 3 & 1 & 4 & 3 & 3 & 20 \\
\hline $\mathrm{V} 21+\mathrm{V} 22$ & 4 & 4 & 1 & 1 & 4 & 4 & 2 & 20 \\
\hline V23 & 4 & 3 & 1 & 1 & 4 & 4 & 1 & 18 \\
\hline
\end{tabular}

\section{Proposals and recommendations}

The proposals and recommendations for Mutha riverfront development are provided in three parts. The first part consists of land use proposals over the vacant lands which were identified along the river. The second part consists of recommendations and development control guidelines for existing development along the river and the third part consists of rectification strategies. 


\subsection{Proposed land use allocation}

In order to accommodate the existing demand for housing in Pune available vacant land in the stretch-1 should be allocated for residential use. Vacant lands along the river in stretch-2 have the maximum potential for recreational and commercial development. Hence most of the recreational and commercial activities have been proposed in this zone. Since the proposed activities would be located within an already developed residential area, it will cater the surrounding residential population and also the population in the newly developed area. Such development would also connect some of the gardens, temples and monuments lying along the river bank creating a network of open space and enhance the pedestrian movement and public access along the river.

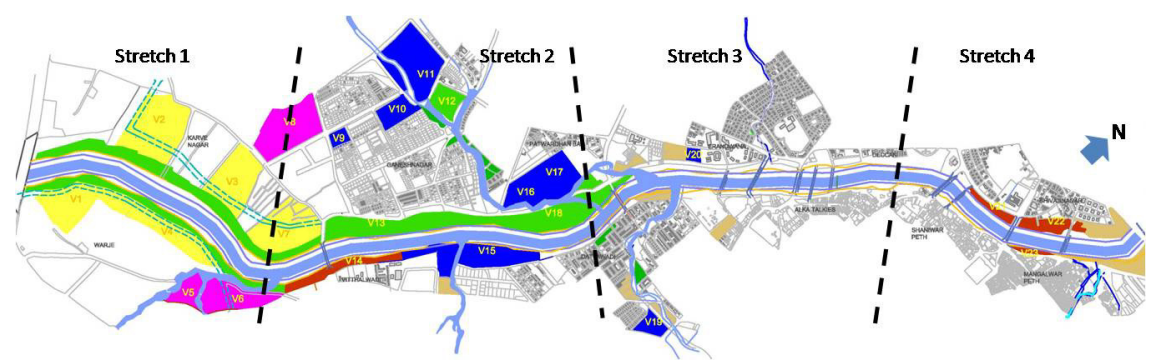

Figure 2: $\quad$ Proposed land use for all stretches.

Stretch-3 and stretch-4 zones are located within the central and core area of the city where not much of the vacant land is available on the river side. This riverfront area is mainly occupied by temples, ghats and some heritage structures. Existing activities along the river may be permitted to continue without any additional developments to grow only due to unavailability of the land and limited capacity of access roads. Existing condition of the ghats should be improved for public interaction and the areas around the heritage structures and temples should be developed with plantation and landscaping.

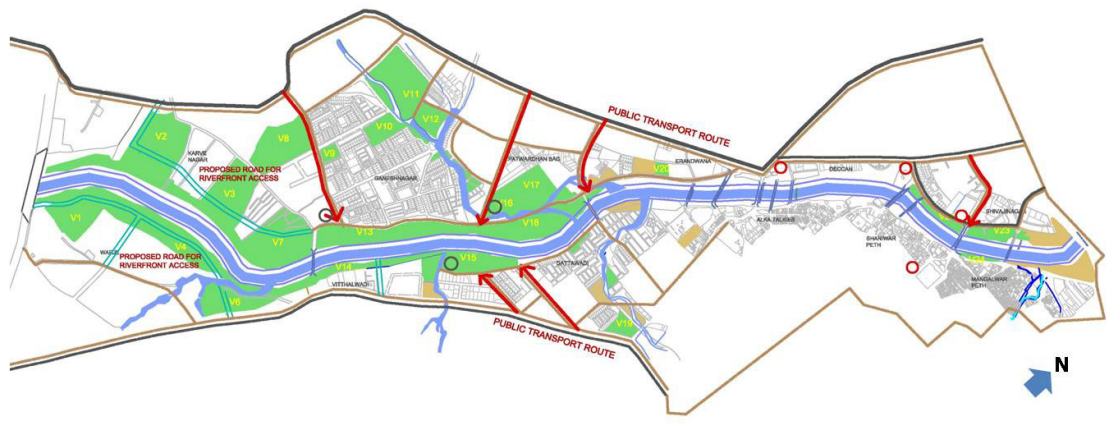

Figure 3: $\quad$ Proposed transportation improvement plan. 


\subsection{Proposals for transportation improvement in the study area}

The riverfront offers a good opportunity for laying a road network along the river that would connect various areas within the city. There lies already a $2.5 \mathrm{~km}$ long riverside road in stretch 2 . This road should be continued along the most of the part of the riverfront which will provide a good access to riverfront activities.

All other major roads should be widened and improved to accommodate enhanced concentration of recreational and associated commercial facilities providing sufficient space for parking of two wheelers and cars in this stretch.

\subsection{Control of development on riverfront zones}

Figure 4 show a typical cross section of riverfront with different opportunities and constraints for allocation of proposed design elements along the total stretch.

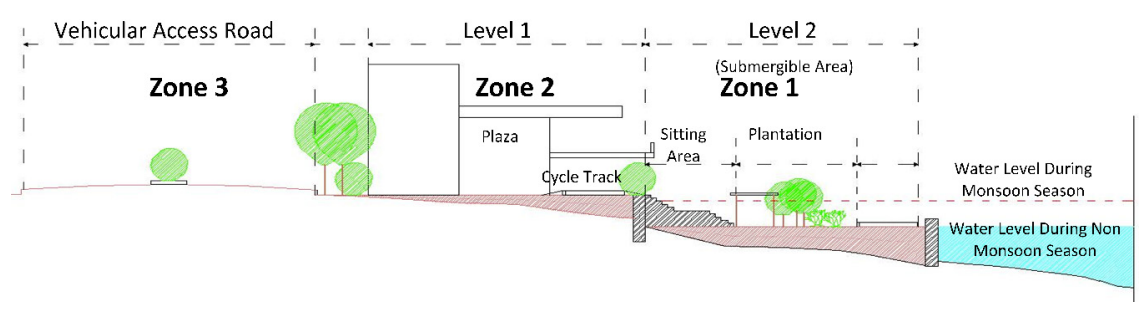

Figure 4: $\quad$ Proposed section for riverfront zones.

Zone-1, which is the strip near the riverbed, is subject to periodic flooding. Hence no permanent structure should be allowed to construct. Only design elements which could withstand periodic flooding during monsoon may be permitted to build.

Zone-2, the area of land between the retaining wall and the vehicular access road, has the maximum potential for development and hence built structures including sports centre, restaurants, plazas, community halls are proposed in this zone. Zone-3 which defines the boundary of riverfront area may be used for vehicle parking areas. All the controls follow the topography of river section.

\subsection{Rectification strategies}

For cleaning and purification of river water six additional sewage treatment plants and two pumping stations have been proposed for treatment of the entire generated sewage and removal of residues from effluent treatment plants at the meeting point of major three creeks/nallas (CWPRS [14]).

Strategies for river bed improvement has been chalked out for "Stream Channelization" of the river and major nallas, silt removal from time to time and correction of gradient. Slum relocation was also advocated to a nearby location to maintain their workplace in close proximity to their residences. Solid waste dumping was another issue that needs to be handled with great care. Provision of garbage disposal units in public places should be implemented. 
A rapid assessment of the financial analysis for the project revealed the NPV value to be Rs.1.5 billion, indicating that the investment in the project would be profitable, mostly through selling of developed government property and thus the civic authority could proceed with the implementation of the project with the help of external assistance.

\section{Conclusion}

For a very rapidly growing city like Pune, the principal challenge is to improve the quality of the river water and its surrounding environment thereby utilising the riverside land for recreational and other functions. For the better bonding between the river and the city it is necessary to open up the riverfront and make it accessible to public. On the other hand due care should be taken to prevent the river environment from degrading through excessive public use (Sairinen and Kumpulainen [17]). This can be achieved by optimal land use planning for the riverfront areas and implementing the activities that are most suitable for the delicate balance of the river environment.

\section{References}

[1] D Henning, et al, Guidelines to develop a Sustainable urban river management plan, Nemai Consulting, 2007

[2] Petts Geoff, Ed, River research and applications, John Wiley \& Sons Ltd, 2002

[3] Bonnie A. Harken, Reshaping Urban Waterfronts, Nautilus International Development Consulting, Inc, 2005

[4] Cristina Santos, Maria Matos Silva, Nadine Soubotin and Theresa Zaro, Planning Strategies for Urban Waterfront Regeneration, 2006

[5] Donald F. Wood, Renewing Urban Waterfronts, Land Economics, Vol. 41, No. 2, pp. 141-149, 1975

[6] Paul Ryckbost, Redeveloping Urban Waterfront Property , Urban \& Regional Planning Economic development hand book, Univ. of Michigan, winter 2005

[7] USAID and Crisal Ltd, City development plan of Pune city, 2005

[8] JNNURM department, Mutha river improvement project report, Pune Municipal Corporation, 2006

[9] Richard Marshall, Waterfronts in post industrial cities, Routledge, 2001

[10] Sarah Wakefield, Great expectations: Waterfront redevelopment and the Hamilton Harbour Waterfront Trail, Cities, Vol. 24, No. 4, p. 298-310, 2007

[11] Seattle Department of Planning and Design, Waterfronts - open spaces and interfaces of edge environments, 2002

[12] Taylor Cullity Lethlean, River Murray Sustainable Recreation Site Planning and Implementation Guide, River Murray Catchments Water Management Board, 2003 
[13] Marta Moretti, Cities on Water and Waterfront Regeneration: A Strategic Challenge for the Future, International Centre Cities on Water, 2007

[14] CWPRS (Central Water And Power Research Centre) GoI, Mutha river improvement project - Water surface profiles, 2002

[15] Environmental lab, Environmental status report, - Pune Municipal Corporation, 2007-08

[16] Frederick Steiner, Laurel McSherry, Jill Cohen, Land suitability analysis for the upper Gila River watershed, landscape and urban planning 50 p.199214,2000

[17] Rauno Sairinen, Satu Kumpulainen, Assessing social impacts in urban waterfront regeneration, environmental impact assessment review 26 p. 120135,2005 